\title{
Erratum to: On the Composition and Age of Taphofloras of the Krivorechenskaya Formation (Upper Cretaceous) of the Anadyr River Left Bank, Northeast Asia
}

\author{
A. B. Herman ${ }^{a, *}$ and S. V. Shczepetov ${ }^{b, * *}$ \\ ${ }^{a}$ Geological Institute, Russian Academy of Sciences, Moscow, 119017 Russia \\ ${ }^{b}$ Komarov Botanical Institute, Russian Academy of Sciences, St. Petersburg, 197376 Russia \\ *e-mail:alexeiherman@yandex.ru \\ **e-mail: shchepetov@mail.ru
}

DOI: $10.1134 / \mathrm{S} 0869593821330017$

The article "On the Composition and Age of Taphofloras of the Krivorechenskaya Formation (Upper Cretaceous) of the Anadyr River Left Bank, Northeast Asia", written by A. B. Herman and S. V. Shczepetov, was originally published electronically in Springer-Link on 5.10. 2021 without Open Access. After publication in volume 29, issue 5, pages 504-517 the authors decided to make the article an Open Access publication. Therefore, the copyright of the article has been changed to (C) The Author(s) 2021 and the article is forthwith distributed under the terms of a Creative Commons Attribution 4.0 International License (http://creativecommons.org/ licenses/by/4.0/, CC BY), which permits use, duplication, adaptation, distribution and reproduction of a work in any medium or format, as long as you cite the original author(s) and publication source, provide a link to the Creative Commons license, and indicate if changes were made.

The original article can be found online at https://doi.org/10.1134/S0869593821050051 